\title{
Activated carbon from cassava peel: A promising electrode material for supercapacitors
}

Carbones activados a partir de cáscara de yuca: Un potencial material como electrodo en supercondensadores

\author{
Julie Ospino (D)1, Juliana Paola Parra-Barraza (D) ${ }^{1}$, Sigifredo Cervera (iD) ${ }^{1}$, Euler E. Coral-Escobar (D) ${ }^{2}$, \\ Oscar Andrés Vargas-Ceballos iD ${ }^{3 *}$ \\ ${ }^{1}$ Programa de Ingeniería Química, Facultad de Ingeniería, Universidad del Atlántico. Carrera 30 \# 8- 49. C. P. 081007. \\ Puerto Colombia, Colombia. \\ ${ }^{2}$ Programa de Física, Facultad de Ciencias Básicas, Universidad del Atlántico. Carrera 30 \# 8- 49. C. P. 081007. Puerto \\ Colombia, Colombia. \\ ${ }^{3}$ Escuela de Ingeniería Metalúrgica y Ciencia de Materiales, Universidad Industrial de Santander. Carrera 27 Calle 9. C. \\ P. 680002. Bucaramanga, Colombia.
}

\section{CITE THIS ARTICLE AS:}

J. Ospino, J. P. Parra, S. Cervera, E. E. Coral and O. A. Vargas. "Activated carbon from cassava peel: A promising electrode material for supercapacitors", Revista Facultad de Ingeniería Universidad de Antioquia, no. 102, pp. 88-95, Jan-Mar 2022. [Online]. Available: https : //www.doi.org/10.17533/ udea.redin. 20200803

\section{ARTICLE INF0:}

Received: November 18, 2019 Accepted: August 10, 2019

Available online: August 10, 2019

\section{KEYWORDS:}

Supercapacitors; energy storage; biomass energy; cassava peels

Supercondensadores; almacenamiento de energía; energía de la biomasa; cáscara de yuca
ABSTRACT: Supercapacitors are conventional devices in electrical circuits that produce electrical pulses at high power levels in short periods. Electrodes for supercapacitors were prepared with activated carbon. Activated carbon was obtained from cassava peels treated by chemical activation with potassium hydroxide $(\mathrm{KOH})$ and phosphoric acid $\left(\mathrm{H}_{3} \mathrm{PO}_{4}\right)$, each at two different concentrations and at one carbonization temperature. The electrochemical performance of the prepared electrodes was obtained by means of cyclic voltammetry and galvanostatic charge-discharge in a 3-electrode system with an electrolytic solution of sulfuric acid $\left(\mathrm{H}_{2} \mathrm{SO}_{4}\right) 1 \mathrm{M}$. Cyclic voltammetry allowed identifying the behavior of supercapacitors in a potential window of $-0.4 \mathrm{~V}$ to $0.6 \mathrm{~V}$. Activated carbon derived from cassava peel with the highest specific surface area $\left(398.46 \mathrm{~m}^{2} / \mathrm{g}\right)$ has exhibited the maximum specific capacitance of $64.18 \mathrm{~F} / \mathrm{g}$.

RESUMEN: Los supercondensadores son dispositivos eléctricos, comunes en circuitos eléctricos, que producen pulsos eléctricos de alta potencia en cortos periodos de tiempo. Los electrodos para los supercondensadores, de este trabajo, fueron preparados con carbón activado. Los carbones activados fueron obtenidos a partir de cáscara de yuca, la cual se trató mediante activación química con hidróxido de potasio $(\mathrm{KOH})$ y ácido fosfórico (H3P04), cada uno a dos diferentes concentraciones y a una temperatura de carbonización. El desempeño electroquímico de los electrodos preparados fue obtenido por medio de pruebas de voltametría cíclica y ensayos de carga-descarga galvanostática, en un sistema de tres electrodos con ácido sulfúrico (H2SO4) 1 M como solución electrolítica. La voltametría cíclica permitió identificar el comportamiento capacitivo en una ventana de potencia de $-0,4 \mathrm{~V}$ a $0,6 \mathrm{~V}$. Los carbones activados, derivados de cáscara de yuca, con la mayor área superficial específica $\left(398,46 \mathrm{~m}^{2} / \mathrm{g}\right)$ exhibieron la mayor capacitancia específica, alrededor de $64 \mathrm{~F} / \mathrm{g}$.

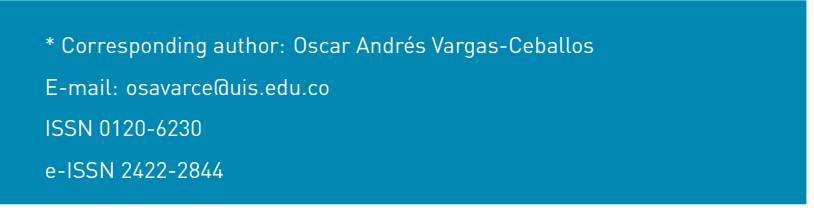

\section{Introduction}

Modern life requires a huge amount of energy. One of the most demanded sources is the energy stored in electrical devices; telecommunication devices, energy reservation systems, and electric vehicles, among others, are some of the top applications requiring stored energy. The devices 
used for energy storage applications must have high power and energy densities; they must be made of low-cost and long-lasting materials [1]. The present energy demand has resulted in the search and development of new energy storage devices, which must be more efficient, portable, and high-power deliverers. Supercapacitors are devices with a higher energy density than common capacitors and a higher power density than batteries [2].

Electrodes for supercapacitors can be made of carbon, metal oxides, and polymeric materials. The most significant electrodes have been those prepared based on carbon since they have a high conductivity, are easily accessible, their costs are relatively low, and they work in a wide temperature range $[2,3]$. The current commercial supercapacitor electrodes are carbon-based and use electrolytes from alkali or alkaline earth metal salts. Such carbon-based supercapacitors have been developed over time by different authors, to increase the capacitance and useful life [1].

Previous research has shown that activated carbon produced from coffee waste [4], tea waste [5], corn straw [6], cotton stem [7], hemp [8], coconut husk [9], among others, have been used as electrode materials for supercapacitors, due to the large reserves of biomass raw materials, their low cost, and good electrochemical performance. In this work, a common residue such as cassava peel is studied for its electrochemical properties and its possibility of use as electrode material in supercapacitors.

\section{Materials and methods}

\subsection{Materials}

Table 1 shows the different chemical reagents used in the synthesis of electrode materials, all of them have been purchased to Merck.

Table 1 Chemicals reagents

\begin{tabular}{cc}
\hline Reagent & Purity \\
\hline Sulfuric acid & $98 \%$ \\
Potassium hydroxide & - \\
Phosphoric acid & $85 \%$ \\
Graphite powder & $96 \%$ \\
Carboxymethylcellulose & - \\
\hline
\end{tabular}

Samples of cassava peel were taken from some restaurants of Barranquilla city; samples have been washed with water and dried during 12 hours with solar radiation to remove excess moisture. Dry peel samples were size-reduced in a blade mill (SIEMENS 1RF3 098-2YD90), working at $2.0 \mathrm{HP}$ and $60 \mathrm{~Hz}$. Powdered peel was sieved in a No. 35 ASTM mesh; the finer particles, after sieving, have been treated with a solution of sulfuric acid $(0.1 \mathrm{M})$ in a mass ratio of $1: 3$, in order to remove the impurities by leaching, acid treatment was followed by rinsing with distilled water until a neutral $\mathrm{pH}$ was obtained. After 2 hours of the drying process, the pulverized peel was carbonized under nitrogen atmosphere.

Carbonization temperature was determined by means of thermogravimetric analysis. A sample was subjected to a heat treatment in a TA Instruments Modulated TGA 2950 Thermogravimetric Analysis equipment. This procedure was carried out at a rate of $10^{\circ} \mathrm{C} / \mathrm{min}$ up to $830^{\circ} \mathrm{C}$, under inert atmosphere $\left(\mathrm{N}_{2}\right)$. The activated carbon was obtained through chemical activation with potassium hydroxide (KOH) solutions at $20 \%$ and $70 \% \mathrm{w} / \mathrm{v}$; and phosphoric acid $\left(\mathrm{H}_{3} \mathrm{PO}_{4}\right)$ solutions at $20 \%$ and $70 \% \mathrm{v} / \mathrm{v}$. The chemical impregnation with each of the solutions was carried out in a carbon:solution ratio of 1:8 p/v for 15 hours. Additionally, impregnated samples were rinsed with distilled water to remove the excesses of the solutions until a neutral $\mathrm{pH}$ was obtained. Samples were dried at a temperature of $110^{\circ} \mathrm{C}$ for 5 hours. The carbonization took place in a furnace for 1 hour at a temperature of $550{ }^{\circ} \mathrm{C}$ in an inert atmosphere $\left(\mathrm{N}_{2}\right)$.

\subsection{Characterization}

Functional groups, present on the surface of the carbon, were determined by means of Fourier-transform infrared (FT-IR) spectroscopy in a spectrophotometer Shimadzu IR Affinity-1 with absorbent optics of Potassium Bromide. The spectral range of work was from $400 \mathrm{~cm}^{-1}$ to 4000 $\mathrm{cm}^{-1}$, in transmittance mode. As further analysis of the chemical composition, the elemental composition of the obtained carbons was characterized in a Sundy elemental analyzer SDCHN435 Carbon Hydrogen \& Nitrogen Analyzer. Regarding to oxygen content, this must be obtained as the difference of the total amount of activated carbon and $\mathrm{C}, \mathrm{N}, \mathrm{H}$ and ash content. The ash determination was made based on ASTM D3174-04 standard in a Terrigeno D8 multipurpose electric muffle. The textural properties of the carbon are paramount characteristics regarding capacitive performance; such properties were examined by adsorbing $\mathrm{N}_{2}$ at $77 \mathrm{~K}$ on a Micromeritics ASAP 2020 PLUS sortometer. The surface area was determined from the adsorption curve of $\mathrm{N}_{2}$ using the BET equation.

\subsection{Electrochemical performance}

Working electrodes were prepared by suspending activated carbon, graphite, and carboxymethylcellulose (CMC) in a ratio of 85:5:10 (w/w) in deionized water. Such a suspension was coated on a stainless-steel mesh 
(300 $\mu \mathrm{m}$ ), the coating was $1 \mathrm{~cm}^{2}$, the coated mesh was dried for 30 minutes at $110{ }^{\circ} \mathrm{C}$. The working electrodes have an average mass of $0.071 \mathrm{~g}$. In order to test the electrochemical performance of the electrodes, electrochemical analyses were performed by means of cyclic voltammetry and galvanostatic charge-discharge techniques in a potentiostat-galvanostat Gamry interface 1000E. A three-electrode cell, with saturated calomel reference electrode (SCE) and counter electrode (graphite), was used in an electrolytic solution of sulfuric acid $\left(\mathrm{H}_{2} \mathrm{SO}_{4}\right)$ at $1 \mathrm{M}$. The determination of the specific capacitance may be calculated by means of Equation 1 and the energy density of the supercapacitors is determined by the Equation 2:

$$
C_{s p}(F / g)=\frac{\int_{E_{0}}^{E_{f}} I d V}{s \Delta V m}
$$

Where $C_{s p}$ is the specific capacitance, $I$ is the current in amperes, $\triangle V$ is the working potential window, $s$ is the sweep speed, $E_{f}$ and $E_{0}$ are the potential limits and $m$ the active mass of the electrode.

$$
E(W h / k g)=\frac{1}{2} C_{s p} V^{2}
$$

Where $E$ is the energy density and $V$ the voltage.

\section{Results and discussion}

\subsection{Chemical and textural properties}

Figure 1 shows the thermogram of the precursor material (cassava peel). In the first temperature range from 20 ${ }^{\circ} \mathrm{C}$ to $110^{\circ} \mathrm{C}$, there is a weight loss of about $7.8 \%$ of the initial mass due to the moisture contained in the sample. A second range, which goes up to $700^{\circ} \mathrm{C}$, exhibits a loss of weight due to the decomposition of lignocellulosic materials. With this data, it was determined that the raw material's carbonization temperature would be between a range of $500^{\circ} \mathrm{C}$ and $600^{\circ} \mathrm{C}$, since in this range there is not yet a total decomposition of the material. Four types of carbons were obtained regarding the type of chemical agent and the concentration of the impregnating agent, carbonization temperature was fixed at $550^{\circ} \mathrm{C}$, as well as carbonization time $(1 \mathrm{~h})$. Table 2 shows the labels used to identify the obtained carbons.

Table 2 Classification of activated carbon obtained from cassava

peels

\begin{tabular}{c|c}
\hline Type & Specification \\
\hline CB-70 & Impregnation with potassium hydroxide $70 \% \mathrm{w} / \mathrm{v}$ \\
CB-20 & Impregnation with potassium hydroxide $20 \% \mathrm{w} / \mathrm{v}$ \\
CA-70 & Impregnation with phosphoric acid $70 \% \mathrm{v} / \mathrm{v}$ \\
CA-20 & Impregnation with phosphoric acid $20 \% \mathrm{v} / \mathrm{v}$ \\
\hline
\end{tabular}

Figure 2 shows the FT-IR spectra for the activated carbon

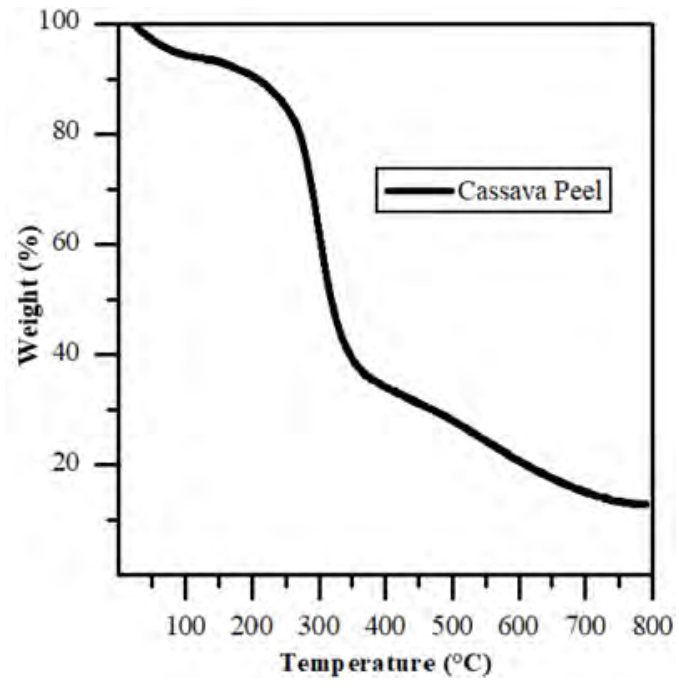

Figure 1 Cassava peel thermogram

samples. It is inferred from them, that the four carbons exhibit similar characteristic bands in transmittance mode; in other words, the samples present the same functional groups. It is noticeable the presence of an intense band between $3200 \mathrm{~cm}^{-1}$ and $3650 \mathrm{~cm}^{-1}$, such a band is associated with the vibration of the stretching and flexion of the $\mathrm{O}-\mathrm{H}$ bond; the band located between 1600 $\mathrm{cm}^{-1}$ and $1800 \mathrm{~cm}^{-1}$ is usually assigned to the functional group $\mathrm{C}=\mathrm{C}$, also assigned to $-\mathrm{CH}_{3}$ groups and chains of $-\left(\mathrm{CH}_{2}\right)_{n}$ - with $\mathrm{n} \geq 4$ according to the double signal in the ranges of $2800-3000 \mathrm{~cm}^{-1}$ and their subsequent signal in the bands corresponding to the range $1385-1365 \mathrm{~cm}^{-1}$ and $730-710 \mathrm{~cm}^{-1}[10]$.

Table 3 shows the results of an elemental analysis performed to the four activated carbons; there are significant differences among them in terms of carbon, nitrogen, oxygen, and ash content. However, the observed variation in the carbon amount is just apparent, since on an ash-free basis, these differences are negligible; on the other hand, nitrogen content does exhibit differences even in ash-free basis. Therefore, the treatment with both activating agents, $\mathrm{KOH}$ and $\mathrm{H}_{3} \mathrm{PO}_{4}$, does favor the decomposition of organic matter when carbonizing, but $\mathrm{KOH}$ treatment does not favor the retention of nitrogen functional groups after heat treatment. Ash content is high in these samples, higher in $\mathrm{KOH}$ treated samples than in the acid treated.

Additionally, the oxygen content was determined by the difference between the contents of carbon, nitrogen, and oxygen, as well as the ash content in the sample, it is worth clarifying that this oxygen content amounts only the oxygen from functional groups linked to the carbon, oxygen in oxides is amounted in ash content. 

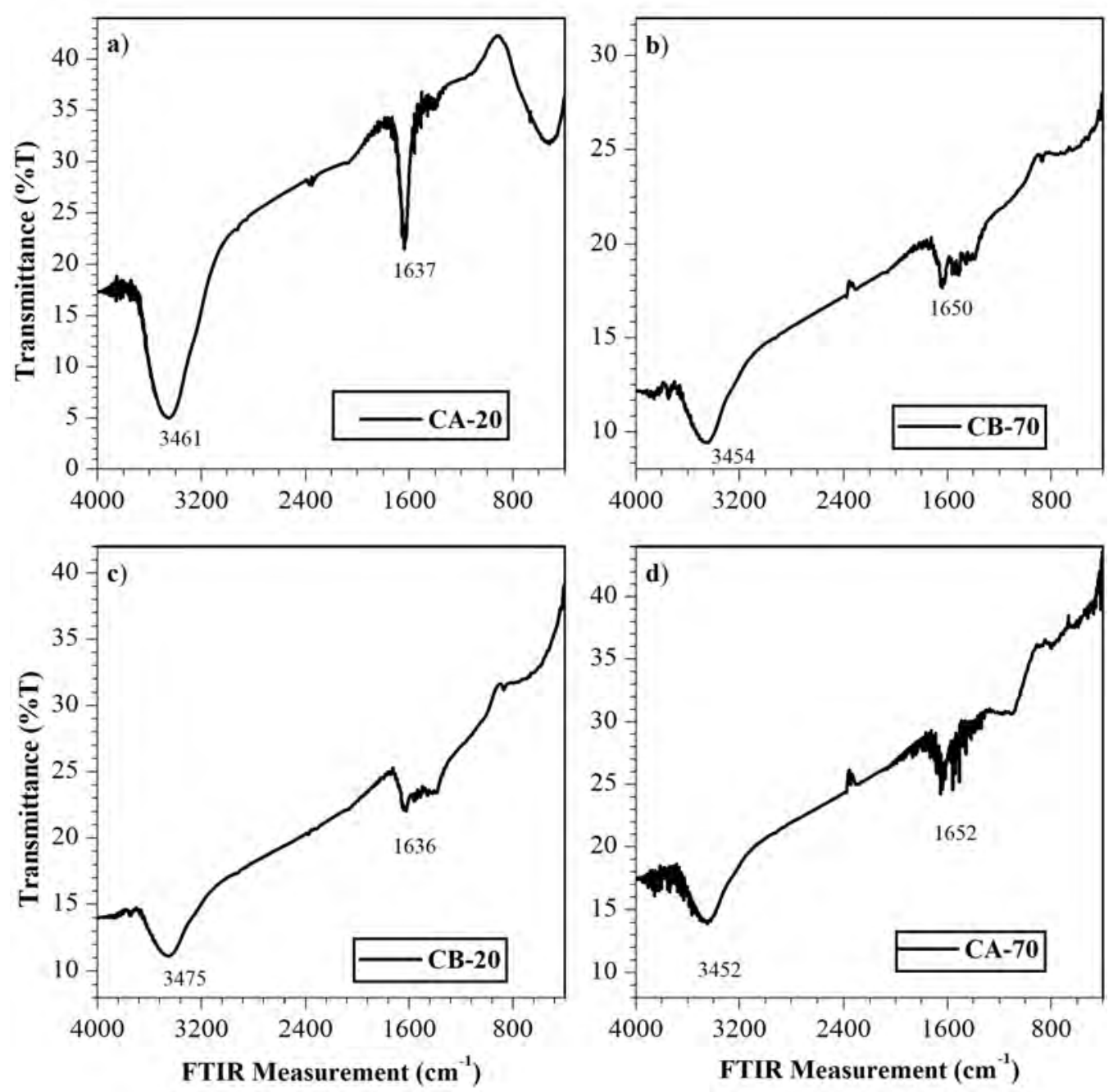

Figure 2 FT-IR spectra of activated carbons CA-20, CA-70, CB-20, CB-70

Table 3 Elemental analysis and ash content present in the activated carbons after treatment with different impregnation agents.

(Percents are on a dry basis)

\begin{tabular}{cccccc}
\hline Sample & \% Carbon & \% Hydrogen & \% Nitrogen & \% 0xygen & \% Ash \\
\hline CB-70 & 61.14 & 2.44 & 0.38 & 9.72 & 26.32 \\
CB-20 & 58.92 & 2.40 & 0.33 & 5.59 & 32.76 \\
CA-70 & 69.43 & 2.70 & 1.43 & 6.21 & 20.23 \\
CA-20 & 69.27 & 2.73 & 1.77 & 6.63 & 19.60 \\
\hline
\end{tabular}

In addition to the chemical composition, and among the paramount characteristics in supercapacitors materials, are surface area and pore volume; these textural properties are summarized in Table 4. The differences observed in the surface area of the resulting carbons are related to the concentration of the chemical agent; the higher the activating agent concentration, the higher the surface area and the pore volume. This behavior has been exhibited by carbons activated with $\mathrm{H}_{3} \mathrm{PO}_{4}$, according to different authors [11-13], and is also present in carbons with $\mathrm{KOH}$ activation $[8,14]$. Such behavior is due to greater interaction between the activating agent and the precursor material [11]. Some authors show that the chemical activation with phosphoric acid promotes the dilation of the precursor material, which afterward the removal of the acid, leaves the matrix in an expanded state with a porous structure; this can be evidenced with the results in this work. According to previous studies [13], this expansion is obtained in both, micro and mesopores, there is an increase in both pores' volumes, but micropore volume gets to a constant volume while mesopores keep growing. 


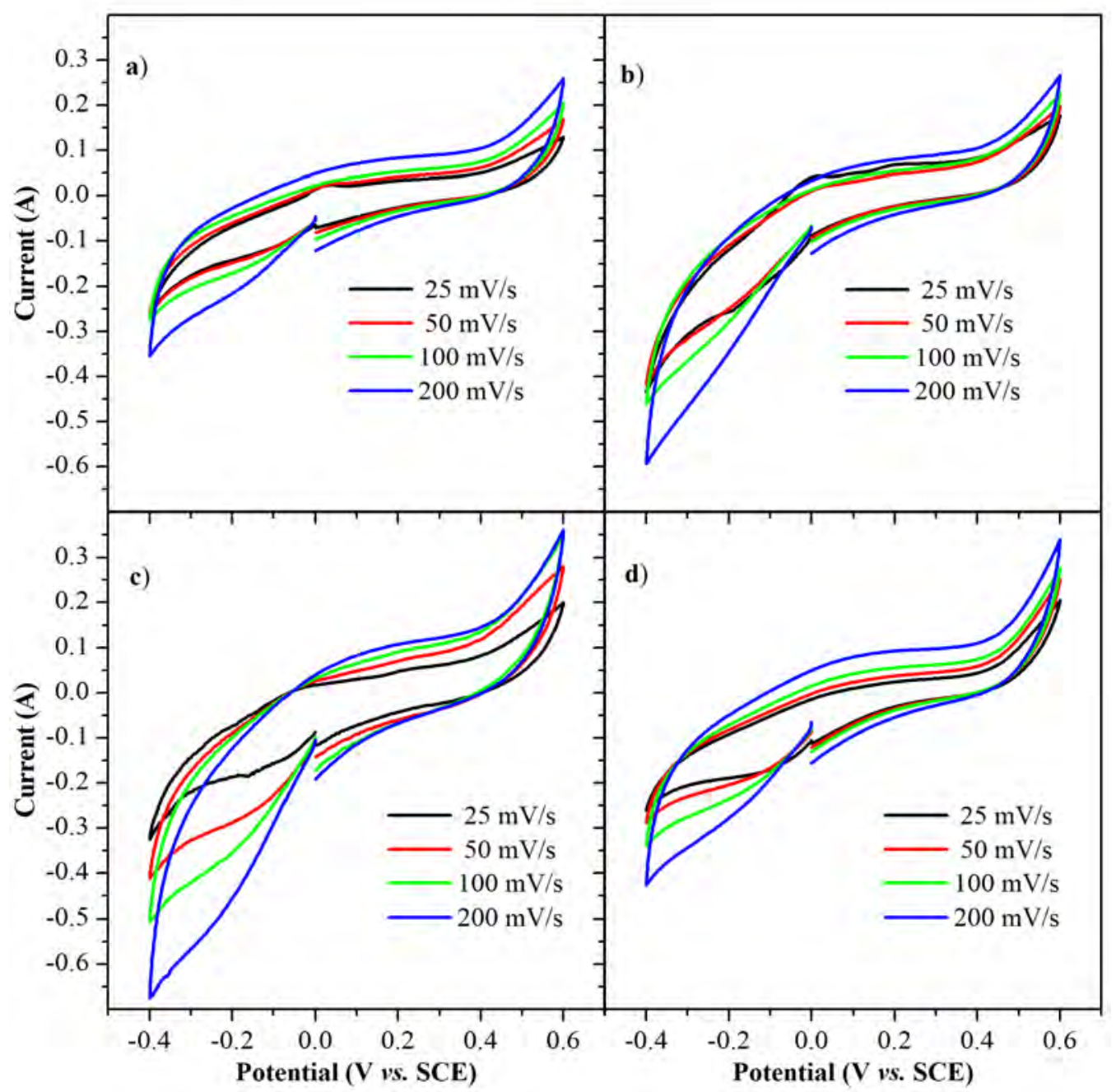

Figure 3 Cyclic voltammetry of a 3-electrode (SCE as reference and graphite as counter) configuration in a $1 \mathrm{M} \mathrm{H}_{2} \mathrm{SO}_{4}$ solution: a) CB-70, b) CB-20, c) CA-70 and d) CA-20

According to the characterization, phosphoric acid treatment allows activated carbons to be obtained with a lower ash content, a higher content of nitrogen functional groups, and a higher surface area and total pore volume than $\mathrm{KOH}$ treatment. In addition, a higher concentration of the acid activating agent renders a carbon with higher values of its textural properties, but a lower content of nitrogen functional groups.

Table 4 Surface area and pore volume of activated carbon

\begin{tabular}{|c|c|c|}
\hline Sample & Surface area $\left(\mathrm{m}^{2} / \mathrm{g}\right)$ & Pore volume $\left(\mathrm{cm}^{3} / \mathrm{g}\right)$ \\
\hline CB-70 & 304.21 & 0.1379 \\
\hline CB-20 & 223.92 & 0.0918 \\
\hline CA-70 & 398.46 & 0.1639 \\
\hline CA-20 & 296.58 & 0.1238 \\
\hline
\end{tabular}

\subsection{Electrochemical performance}

As seen in Figures 3a-d, the cyclic voltammetry curves show an almost rectangular behavior within a working window of $-0.4 \mathrm{~V}$ to $0.6 \mathrm{~V}$ at four different potential rates $(25 \mathrm{mV} / \mathrm{s}, 50 \mathrm{mV} / \mathrm{s}, 100 \mathrm{mV} / \mathrm{s}$ and $200 \mathrm{mV} / \mathrm{s})$, this suggests a capacitive electrochemical behavior. Such capacitive behavior is retained with no regard of the potential rates studied, which is related to the absence of diffusional hindrance. Because of the content of functional groups, especially oxygen and nitrogen functional groups, the obtained capacitance should be the sum of pure capacitance due to the electrical double layer formation in the surface of the activated carbon, plus a kind of pseudocapacitance due to the reversible oxidation/reduction of the functional groups [15]. However, in voltammetry curves there is no evidence of any redox peak at the applied potential rates. 
Table 5 Electrochemical characterization by means of the cyclic voltammetry technique for the electrodes of CA-20, CA-70, CB-20, CB-70 in an electrolytic solution of $\mathrm{H}_{2} \mathrm{SO}_{4}$ at $1 \mathrm{M}$

\begin{tabular}{|c|c|c|c|c|}
\hline Sample & $\begin{array}{l}\text { Concentration of } \\
\mathrm{H}_{2} \mathrm{SO}_{4} \text { electrolytic } \\
\text { solution }\end{array}$ & $\begin{array}{c}\text { Potential rate } \\
\text { (V/s) }\end{array}$ & $\begin{array}{c}\text { Specific } \\
\text { Capacitance } \\
\text { (F/g) }\end{array}$ & $\begin{array}{c}\text { Energy Density } \\
\text { (Wh/kg) }\end{array}$ \\
\hline \multirow{4}{*}{ CB-70 } & \multirow{4}{*}{$1 \mathrm{M}$} & 0.025 & 62.16 & 8.63 \\
\hline & & 0.050 & 54.16 & 7.52 \\
\hline & & 0.100 & 32.20 & 4.47 \\
\hline & & 0.200 & 19.40 & 2.69 \\
\hline \multirow{4}{*}{ CB-20 } & \multirow{4}{*}{$1 \mathrm{M}$} & 0.025 & 44.84 & 6.23 \\
\hline & & 0.050 & 27.58 & 3.83 \\
\hline & & 0.100 & 17.83 & 2.48 \\
\hline & & 0.200 & 12.92 & 1.79 \\
\hline \multirow{4}{*}{ CA-70 } & \multirow{4}{*}{$1 \mathrm{M}$} & 0.025 & 64.18 & 8.91 \\
\hline & & 0.050 & 31.31 & 4.35 \\
\hline & & 0.100 & 16.08 & 2.23 \\
\hline & & 0.200 & 11.23 & 1.56 \\
\hline \multirow{4}{*}{ CA-20 } & \multirow{4}{*}{$1 \mathrm{M}$} & 0.025 & 58.46 & 8.12 \\
\hline & & 0.050 & 27.03 & 3.75 \\
\hline & & 0.100 & 16.70 & 2.32 \\
\hline & & 0.200 & 11.58 & 1.61 \\
\hline
\end{tabular}

The surface functional groups of heteroatoms, such as oxygen and nitrogen, improve the ion adsorption process, which improves and facilitates the rapid transport of electrolyte ions within the micropores of the electrode. Furthermore, the higher electronegativity of oxygen promotes an increase in polarity of activated carbon which results in a higher hydrophilicity [4] [16-18], the higher the water affinity of the carbon, the higher the ion adsorption rates.

In Table 5, the specific capacitance and energy density data, calculated with Equations 1 and 2, are collected. At a lower potential rate, the capacitance and the energy density of the cell are higher; this is due to the higher transfer of charge during the travel of the electrolyte and its greater diffusion through the pores of the active material of the electrode. Carbons with the best performance are CA-70 and CB-70; these carbons have the highest surface area, $398.46 \mathrm{~m}^{2} / \mathrm{g}$ and $304.20 \mathrm{~m}^{2} / \mathrm{g}$, respectively; such high surface favors the accumulation of charge at the electrode-electrolyte interface and the pore volume allows the ions to enter with a lower hindrance. Acid activated carbons exhibit higher capacitance than alkaline activated carbons at lower potential rates, this is related to a higher content in nitrogen functional groups and carbon content, which is related to a higher conductivity; it is also related to a higher surface area. However, at higher potential rates, the best behavior has been exhibited by CB-70, despite its lower contents in nitrogen and carbon, and higher ash content. CB-70 is the carbon with the highest oxygen content, such a result indicates that the oxygen functional groups have a higher effect on surface wettability, which is beneficial in order allow the fast absorption of an ion at higher potential rates.

Table 6 compares the capacitive performance of carbon prepared with cassava peel with activated carbons obtained from other biomass sources. It is evident that capacitance is directly related to the surface area of the carbonaceous material. Capacitances of the cassava peel-based carbons, prepared here, are lower than those presented in the table, because they have a smaller surface area. Acid treatment leads to an active carbon with properties that allow a better performance of the electrodes in supercapacitors, and the higher the concentration of such activating agent, the higher the capacitance, since a higher surface area is achieved.

To the best of our knowledge, there is only one work [16] in which supercapacitor electrodes have been prepared from cassava peel. Our material seems to be promising, as long as the synthetic procedure gets more control and further treatment gives higher surface areas and lower ash content.

Finally, galvanostatic charge/discharge, at a current rate of $0.1 \mathrm{~mA}$ and through 2000 cycles, shows additional evidence on the good performance of the cassava peel-based supercapacitors. First discharge is high for the four samples, ranging from 63 to $79 \mathrm{~F} / \mathrm{g}$, as shown in Table 7, the higher initial capacitance is for CA-70 sample, $78.71 \mathrm{~F} / \mathrm{g}$, confirming what has been obtained by means of cyclic voltammetry. As expected, after some cycles the discharge capacity fades to an almost constant value, so 
Table 6 Comparison with other carbon materials based on biomass

\begin{tabular}{|c|c|c|c|c|c|}
\hline Precursor material & Activating agent & Electrolyte & Surface area $\left(\mathrm{m}^{2} / \mathrm{g}\right)$ & Capacitance (F/g) & Literature \\
\hline \multirow{4}{*}{ Cassava peel } & $\mathrm{KOH} \mathrm{70 \%}$ & $\mathrm{H}_{2} \mathrm{SO}_{4} 1 \mathrm{M}$ & 304.20 & 62.16 & \multirow{4}{*}{ This Work } \\
\hline & $\mathrm{KOH} 20 \%$ & $\mathrm{H}_{2} \mathrm{SO}_{4} 1 \mathrm{M}$ & 223.91 & 44.83 & \\
\hline & $\mathrm{H}_{3} \mathrm{PO}_{4} 70 \%$ & $\mathrm{H}_{2} \mathrm{SO}_{4} 1 \mathrm{M}$ & 398.46 & 64.18 & \\
\hline & $\mathrm{H}_{3} \mathrm{PO}_{4} 20 \%$ & $\mathrm{H}_{2} \mathrm{SO}_{4} 1 \mathrm{M}$ & 296.58 & 58.46 & \\
\hline Coffee waste & $\mathrm{ZnCl}_{2}$ & $\mathrm{H}_{2} \mathrm{SO}_{4} 1 \mathrm{M}$ & 1019 & 368 & 4 \\
\hline Tea waste & $\mathrm{H}_{3} \mathrm{PO}_{4}$ & $\mathrm{H}_{2} \mathrm{SO}_{4} 1 \mathrm{M}$ & 1327 & 123 & [5] \\
\hline Corn straw & $\mathrm{KOH}$ & $\mathrm{H}_{2} \mathrm{SO}_{4} 1 \mathrm{M}$ & 2790 & 327 & [6] \\
\hline Cotton stem & $\mathrm{KOH}$ & $\mathrm{H}_{2} \mathrm{SO}_{4} 1 \mathrm{M}$ & 1964 & 254 & [7] \\
\hline Hemp & $\mathrm{KOH}$ & $\mathrm{TEMABF}_{4} / \mathrm{PC}$ & 2801 & 160 & [8] \\
\hline Cassava peel & $\mathrm{KOH}$ & $\mathrm{H}_{2} \mathrm{SO}_{4} 0.5 \mathrm{M}$ & 1352 & 153 & [16] \\
\hline Orange peel & $\mathrm{H}_{3} \mathrm{PO}_{4}$ & $\mathrm{H}_{2} \mathrm{SO}_{4} 0.1 \mathrm{M}$ & 509 & 275 & [18] \\
\hline
\end{tabular}

Table 7 Electrochemical performance according to discharge capacitance in galvanostatic charge/discharge cycles for the electrodes of CA-20, CA-70, CB-20, CB-70 in an electrolytic solution of $\mathrm{H}_{2} \mathrm{SO}_{4}$ at $1 \mathrm{M}$, at a current rate of $0.1 \mathrm{~mA}$

\begin{tabular}{cccccc}
\hline Sample & $\begin{array}{c}\text { Initial } \\
\text { Capacitance (F) }\end{array}$ & $\begin{array}{c}\text { Initial Specific } \\
\text { Capacitance (F/g) }\end{array}$ & $\begin{array}{c}\text { Final } \\
\text { Capacitance (F) }\end{array}$ & $\begin{array}{c}\text { Final Specific } \\
\text { Capacitance (F/g) }\end{array}$ & $\begin{array}{c}\text { Capacitance } \\
\text { Retention (\%) }\end{array}$ \\
\hline CB-70 & 4.04 & 76.68 & 3.09 & 58.71 & 76.56 \\
CB-20 & 3.81 & 62.34 & 3.29 & 53.82 & 86.34 \\
CA-70 & 4.82 & 78.71 & 3.22 & 52.70 & 66.95 \\
CA-20 & 4.18 & 63.08 & 3.16 & 47.60 & 75.47 \\
\hline
\end{tabular}

that discharge at the $2000^{\text {th }}$ cycle ranges from 47 to 59 $\mathrm{F} / \mathrm{g}$. Despite a high initial discharge capacitance, CA-70 exhibits the highest loss in capacitance, with the lower capacitance retention $(66.95 \%)$ among the four samples. Such a loss in capacitance could be due to a concomitant loss of nitrogen functional groups, since these groups have been attributed as enhancers of conductivity in acid activated carbons. Post-cycling elemental analysis are necessary in order to check this hypothesis.

\section{Conclusion}

A combination of surface properties, surface area and pore volume, with chemical properties, presence of nitrogen heteroatoms, provides a decrease in steric hindrance, a greater polarization area, a greater wettability of the surface and an increased conductivity; this results in a better electrochemical performance of the activated carbons that were produced from cassava peel, which provides nitrogenous functional groups, at high concentrations of activating agent. The results obtained also suggest that cassava peel can become an activated carbon with promising properties for the preparation of supercapacitors; however, it is necessary to be more careful with the treatment of the raw material and the post-activation treatment to reduce the amount of ash present.

\section{Declaration of competing interest}

We declare that we have no significant competing interests including financial or non-financial, professional, or personal interests interfering with the full and objective presentation of the work described in this manuscript.

\section{Acknowledgments}

The authors acknowledge the financial support for conducting this research from Universidad del Atlántico and Universidad Industrial de Santander, special acknowledgment to "PROGRAMA DE APOYO A LA MOVILIDAD DE PROFESORES - Portafolio VIE UIS 2018".

\section{References}

[1] A. Burke, "Ultracapacitors: Why, how, and where is the technology," Journal of Power Sources, vol. 91, no. 1, November 2000. [Online]. Available: https://doi.org/10.1016/S0378-7753(00)00485-7

[2] T. Chen and L. Dai, "Carbon nanomaterials for high-performance supercapacitors," Materials Today, vol. 16, no. 7-8, July 2013. [Online]. Available: https://doi.org/10.1016/j.mattod.2013.07.002

[3] 0. loannidou and A. Zabaniotou, "Agricultural residues as precursors for activated carbon production - A review," Renewable \& Sustainable Energy Reviews, vol. 11, no. 9, December 2007. [Online]. Available: https://doi.org/10.1016/j.rser.2006.03.013

[4] T. E. Rufford, D. Hulicova, Z. Zhu, and G. Qing, "Nanoporous carbon electrode from waste coffee beans for high performance supercapacitors," Electrochemistry Communications, vol. 10, no. 10, 
October 2008. [Online]. Available: https://doi.org/10.1016/j.elecom. 2008.08.022

[5] I. I. Gurten, S. M.vHolmes, A. Banford, and Z. Aktas, "The performance of supercapacitor electrodes developed from chemically activated carbon produced from waste tea," Applied Surface Science, vol. 357, December 01 2015. [Online]. Available: https://doi.org/10.1016/j.apsusc.2015.09.067

[6] Z. Qiu and et al., "Biochar-based carbons with hierarchical micro-meso-macro porosity for high rate and long cycle life supercapacitors," Journal of Power Sources, vol. 376, February 01 2018. [Online]. Available: https://doi.org/10.1016/j.jpowsour.2017. 11.077

[7] X. Tian and et al., "Flute type micropores activated carbon from cotton stalk for high performance supercapacitors," Journal of Power Sources, vol. 359, August 15 2017. [Online]. Available: https://doi.org/10.1016/j.jpowsour.2017.05.054

[8] W. Sun, S. M. Lipka, C. Swartz, D. Williams, and F. Yang, "Hemp-derived activated carbons for supercapacitors," Carbon, vol. 103, July 2016. [Online]. Available: https://doi.org/10.1016/j.carbon. 2016.02 .090

[9] A. Jain and S. K. Tripathi, "Fabrication and characterization of energy storing supercapacitor devices using coconut shell based activated charcoal electrode," Materials Science and Engineering $B$, vol. 183, April 2014. [Online]. Available: https://doi.org/10.1016/j. mseb.2013.12.004

[10] B. C. Smith, Infrared spectral interpretation: A systematic approach. Boca Raton, USA: CRC Press, 1998.

[11] M. Molina, F. RodRíguez, F. Caturla, and M. J. Sellés, "Porosity in granular carbons activated with phosphoric acid," Carbon, vol. 33, no. 8, 1995. [Online]. Available: https://doi.org/10.1016/ 0008-6223(95)00059-M

[12] B. S. Girgis, S. S. Yunis, and A. M. Soliman, "Characteristics of activated carbon from peanut hulls in relation to conditions of preparation," Materials Letter, vol. 57, no. 1, November 2002. [Online]. Available: https://doi.org/10.1016/S0167-577X(02)00724-3

[13] M. Jagtoyen and F. Derbyshire, "Activated carbons from yellow poplar and white oak by $\mathrm{H}_{3} \mathrm{PO}_{4}$ activation," Carbon, vol. 36, no. 7-8, 1998. [Online]. Available: https://doi.org/10.1016/S0008-6223(98) 00082- 7

[14] Y. Sudaryanto, S. B. Hartono, W. Irawaty, H. Hindarso, and S. Ismadji, "High surface area activated carbon prepared from cassava peel by chemical activation," Bioresource Technology, vol. 97, no. 5, March 2006. [Online]. Available: https://doi.org/10.1016/j.biortech.2005. 04.029

[15] S. Li and et al., "An all-in-one material with excellent electrical double-layer capacitance and pseudocapacitance performances for supercapacitor," Applied Surface Science, vol. 453, September 30 2018. [Online]. Available: https://doi.org/10.1016/j.apsusc.2018.05. 088

[16] A. Evan, S. Wang, F. Edi, and S. Ismadji, “Preparation of capacitor's electrode from cassava peel waste," Bioresource Technology, vol. 101, no. 10, May 2010. [Online]. Available: https://doi.org/10.1016/j. biortech.2009.12.123

[17] L. Wei and G. Yushin, "Nanostructured activated carbons from natural precursors for electrical double layer capacitors," Nano Energy, vol. 1, no. 4, July 2012. [Online]. Available: https: //doi.org/10.1016/j.nanoen.2012.05.002

[18] M. Dhelipan, A. Arunchander, A. K. Sahu, and D. Kalpana, "Activated carbon from orange peels as supercapacitor electrode and catalyst support for oxygen reduction reaction in proton exchange membrane fuel cell," Journal of Saudi Chemical Society, vol. 21, no. 4, May 2017. [Online]. Available: https://doi.org/10.1016/j.jscs.2016.12.003 